exhortation. The colour bar is not entirely a product of that racial prejudice and exclusiveness to which such exhortation is addressed. Its roots extend to cultural, social and economic conditions, from which spring problems demanding the closest examination and study before their solution will bring about that co-operation between different classes in the community, each according to its kind and its capacities, instead of present antagonisms. This constitutes the real elimination of the colour bar-a partnership in realities and not a brotherhood by adoption in which the conditions of unity have yet to be attained.

\section{Road Travel in Air Raids}

A NEw aspect of road safety emerges with the decision to allow road traffic to continue during airraid warnings. General agreement seems to have been arrived at that this decision is a wise one. As pointed out in Roads and Road Construction of September 2, the long lines of vehicles held up during the early raids, with their occupants standing about waiting for something to happen, presented an excellent target for machine-guns. It is difficult to see what other course could have been taken. Judging by experience learned from recent raids, many motorists are taking advantage of this concession. Travelling along roads deserted of all but police and A.R.P. personnel is a curious experience; and so is the feeling of frustration in a closed car produced by inability to see what is going on overhead. Something of what is happening can be guessed from the attitude of wardens and others, but in the absence of exact knowledge one tends to develop what has been called a sort of 'musical chairs' attitude towards the public shelters passed when driving, the question now being where the music (?) will start-not when it will stop. It has been suggested that something might be done to give motorists a feeling of greater security, or rather to reduce their feeling of insecurity, by way of signposting shelters along the main traffic routes. In many places signs have already been erected, but these are scarcely conspicuous enough to be seen by passing traffic; they eater more for the local inhabitants. Shops and private houses with surplus shelter accommodation might also be induced to co-operate.

\section{Medicinal Herb Production in Great Britain}

A sHort memorandum, presumably a preliminary one, has been issued by the Ministry of Health declaring its policy regarding the domestic cultivation of medicinal plants and outlining the arrangements which have already been made in respect of belladonna, digitalis, henbane and stramonium. These four potent drugs are to be made the special care of the Ministry, and it is understood that the owners of established herb farms have undertaken to extend the acreages under cultivation. Outside effort is not discouraged; but, as the memorandum states, "Farmers and owners of large private gardens who wish to engage in the cultivation of herbs are recommended to operate in close association with commercial firms to ensure that the crop is properly harvested and dealt with". This is sound advice, and if followed will help amateur gardeners to avoid pitfalls, which are not a few in number. It is hoped that the deficiency of supplies of these four important drugs, which is due to the cessation of imports from Continental sources, will be made up by greatly increased home production. The Ministry has given no guidance with regard to the many other herbs which, although of lesser medical importance than the four specifically named plants, are of considerable commercial interest as household remedies. The matter might perhaps be taken up by the Ministry of Agriculture, and the Board of Education might give official advice about the collection of herbs by school children.

\section{Rectifier Plant in Time of War}

IT has been doubted by some engineers whether the glass bulb devices used in some electric stations for converting alternating into direct current are able to withstand the blast and other effects of aerial bombing. It has to be remembered that the bulbs, being spherical, present a minimum surface to blast contact. They are flexibly mounted and are made of a special toughened high-grade glass. They are always operating under an external atmospheric pressure of approximately $15 \mathrm{lb}$. per sq. in. (as the bulbs are various). This is equivalent to a total pressure of about 20 tons in the case of a large rectifier bulb and so its inherent strength is very considerable. It has been computed that one ton of high explosive will cause a blast pressure of about $2 \frac{1}{2} \mathrm{lb}$. per sq. in. at $100 \mathrm{yd}$. distance. Such a pressure might be sufficient to knock down a 9 -in. brick wall (because of the large resistance surface it presents), for $2 \frac{1}{2} \mathrm{lb}$. per sq. in. is the equivalent of $1 \frac{1}{2}$ tons per sq. yd. A rectifier bulb is always working at $15 \mathrm{lb}$. per sq. in. and can withstand. many times this amount.

A further point is that the bulbs are always installed inside sheet steel cubicles, and the cubicles are generally housed inside a building. The concussion effect that can reach a bulb through the walls of the building and the walls of the cubicles. is only a small fraction of the blast impinged on the external sub-station walls. The bulbs can withstand much higher pressures than the normal sub-station. walls and yet it is the walls that must take the brunt of the blast. Finally, the multi-unit construction of the glass bulb rectifier makes it far less. vulnerable than most other types of plant to the secondary effects of aerial warfare, as for example, shrapnel. Electrical Industries of September 2 points out that a splinter which would be sufficient to put a one-unit type of plant, whether static or rotary, out of operation, would probably damage at most one cubicle of a bulb rectifier plant.

\section{Guide to Fuel and Allied Industries}

The War has profoundly influenced life, industry and technology, and especially in all that concerns fuel and allied industries. Organizations have been modified, their activities suspended and new ones established, As a result people concerned are often at a. 
loss for addresses and sources of information. To meet this need, the Association of Special Libraries and Information Bureaux has issued "ASLIB Guide to British Sources of Specialised Information. No. 1, Fuel and Allied Industries (excluding Electricity)" (2s. 6d. to non-members. ASLIB, 31 Museum Street, London, W.C.1). It indicates what new organizations have arisen and what modifications have been made in war-time. Particulars are given of relevant Government and other departments, professional, trade, and research organizations, university teaching departments and libraries, commercial and industrial organizations, periodicals printing abstracts and references, trade periodicals, periodicals issued by professional bodies and industrial concerns, and annuals. The list is comprehensive, and a perusal failed to note the omission of any address or paper concerned with fuels in war-time. It should find a useful place on the table of everyone concerned with administration or investigation of fuel affairs in these times.

\section{William Withering and Erasmus Darwin}

The June issue of the Bulletin of the History of Medicine contains an interesting notice by Drs. Ruth Musser and John C. Krantz, jun., on the friendship of William Withering and Erasmus Darwin. In 1775, nine years after graduating as M.D. at Edinburgh, Withering, who was in practice at Birmingham, became intimately associated with Erasmus Darwin, an Edinburgh doctor of medicine ten years his senior, and was admitted by him to the Lunar Society which Darwin and others had founded. The outstanding members of this Society were James Watt, Joseph Priestley and Josiah Wedgwood, and the visitors included among others Herschel and Benjamin Franklin. The friendship of Darwin and Withering continued for many years. Each enjoyed a wide reputation and an extensive practice. The greatest contribution which Withering made to posterity was his use of the purple foxglove in the treatment of dropsy, the description of which is to be found in his classical work published in 1785 entitled "The Foxglove, an Account of its Medical Properties", while of Darwin it has been said that there was scarcely an invention in the world to-day that his mind did not foresee. Withering died in 1799 at the relatively early age of fifty-three, but Darwin survived until 1802 , or seven years before the birth of his grandson, the author of "The Origin of Species".

\section{The Newcomen Society}

The Newcomen Society has recently published vol. 19 of its Transactions, its sixth Quarterly Bulletin and its programme of papers for the session 1940-41. Seven meetings have been arranged, and the papers to be presented deal with the history of many subjects, among these being the sugar-cane industry, the iron industry, Henry Corte's bicentenary, the Surrey iron railway, needle-making, wire and plate gauges and the hydraulic extrusion of metals. In the Quarterly Bulletin, reference is made to the movement in the United States to preserve the birthplace of Robert Fulton, and to the erection of a tablet on a granite shaft over the burial place of Oliver Evans, in Trinity Churchyard, Broadway, New York. The 'pilgrimage' of members of the Society in America which was to have taken place in New Hampshire in June was abandoned on the receipt of the news of the defeat of France.

The new volume of the Transactions contains thirteen papers and nine other communications, together with a continuation of the valuable analytical bibliography of the history of engineering The volume runs to 290 pages and contains twenty-four plates. Most of the papers were referred to in our columns at the time they were read. Among the notes and communications is a list of 320 engineering drawings dating from 1775 to 1840 preserved at the Science Museum in the Goodrich Collection, and a description of the first dry dock in the Netherlands (1707) by Lieut. J. J. Bootsgezel, of the Netherland Royal Navy, who, it has been learnt, lost his life through a mine when escaping from Holland. $\mathrm{He}_{\mathrm{e}}$ was well known for his great interest in the records of Dutch engineering. The president of the Society for the current year is Col. C. E. Davies, secretary of the American Society of Mechanical Engineers; his address will be read in both New York and London on November 13.

\section{Electromagnetic Levitation}

Av exhibit which has proved attractive at the Centennial Exhibition of the Dominion of New Zealand is showing an aluminium plate floating in air in a strong alternating-current field and frying eggs in a pan without visible means of heating and support. An iron core is concealed beneath a table top and excited by A.c. windings so arranged and connected that they produce alternating magnetic fields, toroidal in form, of high intensity and opposite polarity. An aluminium pan floats on this field with such definition of position that considerable effort is required to move it downwards or sideways. Heat generated in the pan, by currents induced by the field, does the cooking. It is very suitable as an exhibit for publicity purposes, but at present it does not look as if it has any practical application, as a very large electrical input is required to maintain a magnetic field of suitable form and intensity.

\section{Seismological Data from India}

MUCH useful seismological data is contained in the Seismological Bulletin of April, May and June, 1939, recently published by the Government of India Meteorological Department. It contains interpretations of the seismograms obtained at seven observatories in India and Ceylon together with macroseismic data supplied by voluntary observers in nine regions. About sixty earthquakes were recorded at each of the observatories for the three months, though only nineteen were registered at the Haig Observatory at Dehra Dun. This is not considered significant on account of the types of instruments in use at the stations, a full list of which is given. The region near Shillong appears to have experienced more earthquakes than any other during the period, having had 